\title{
Faktor yang Berhubungan dengan Hiperglikemia dan Luarannya pada Anak Sakit Kritis
}

\author{
Rosary, Imral Chair, Pustika Amalia, Agus Firmansyah, Irawan Mangunatmadja, \\ Mulyadi M. Djer \\ Departemen Ilmu Kesehatan Anak Fakultas Kedokteran Universitas Indonesia/Rumah Sakit Cipto \\ Mangunkusumo, Jakarta
}

\begin{abstract}
Latar belakang. Hiperglikemia pada sakit kritis berhubungan dengan luaran yang lebih buruk, seperti lama penggunaan ventilasi mekanik, dan obat vasoaktif lebih panjang, serta derajat disfungsi organ yang lebih berat.

Tujuan. Mengetahui hubungan karakteristik subjek dengan hiperglikemia serta mengetahui perbedaan proporsi subjek yang mengalami hiperglikemia antara kelompok subjek yang memakai ventilasi mekanik, mendapat obat vasoaktif, serta dengan disfungsi organ berat, dibandingkan dengan kelompok subjek yang tidak.

Metode. Studi analitik potong lintang dilakukan pada anak sakit kritis di Pediatric Intensive Care Unit (PICU) Rumah Sakit Cipto Mangunkusumo (RSCM) usia 1 bulan-18 tahun, dilakukan antara Maret-Juni 2011. Hasil. Didapatkan 87 subjek penelitian, 60 di antaranya laki-laki. Hiperglikemia ditemukan pada 25/87 $(28,7 \%)$ subjek dengan median kadar glukosa darah 121 (37-443) mg/dL Hiperglikemia ditemukan lebih banyak pada laki-laki, usia >1-5 tahun, gizi kurang, dan pasca-bedah, tetapi tidak ditemukan hubungan yang bermakna. Subjek yang menggunakan ventilasi mekanik dan vasoaktif memiliki proporsi lebih besar mengalami hiperglikemia dibandingkan dengan subjek yang tidak, tetapi perbedaan ini juga tidak bermakna. Enam dari 10 subjek yang memiliki skor Pediatric Logistic Organ Dysfunction (PELOD) tinggi mengalami hiperglikemia. Proporsi ini lebih besar dibandingkan subjek dengan skor PELOD rendah, yaitu 19/77 subjek ( $\mathrm{p}=0,03)$.

Kesimpulan. Proporsi subjek yang mengalami hiperglikemia lebih besar pada anak dengan disfungsi organ berat daripada disfungsi organ ringan. Karakteristik subjek tidak berhubungan dengan hiperglikemia pada sakit kritis. Tidak terbukti adanya perbedaan proporsi subjek yang mengalami hiperglikemia pada anak sakit kritis yang menggunakan ventilasi mekanik dan obat vasoaktif dibandingkan dengan kelompok subjek yang tidak. Sari Pediatri 2013;15(1):32-8.
\end{abstract}

Kata kunci: hiperglikemia, sakit kritis, luaran, skor PELOD

Alamat korespondensi:

Dr. Rosary, Sp.A. RSIA RP Soeroso. Jl. Aria Putra 9 Kedaung Pamulang,

Tangerang. Telp. (021) 7400956. E-mail: dr.rosari@idai.or.id 
S akit kritis dapat memicu respons fase akut yang berhubungan dengan beberapa gangguan metabolik berat, meliputi hiperglikemia, dislipidemia, pemecahan protein yang berlebihan sebagai substrat untuk penyembuhan jaringan, serta sintesis protein fase akut dan glukosa di hati. ${ }^{1-3}$ Respons stres metabolik akut antara lain ditandai dengan penglepasan sitokin dan sekresi hormon counter-regulatory, seperti katekolamin, glukagon, dan kortisol yang bekerja berlawanan dengan efek insulin. Hormon ini juga menyebabkan terjadinya glikogenolisis, glukoneogenesis, dan jalur metabolik lainnya, akhirnya menyebabkan hiperglikemia. Pelepasan sitokin proinflamasi juga memperberat keadaan hiperglikemia. Selain itu, hiperglikemia pada keadaan sakit kritis juga dapat diakibatkan oleh penggunaan kortikosteroid, obat golongan adrenergik dan pemberian cairan dekstrosa konsentrasi tinggi untuk nutrisi. ${ }^{4-6}$

Dahulu, hiperglikemia sering ditemukan pada pasien sakit kritis dan diduga sebagai respons adaptasi fisiologis dan bersifat menguntungkan pada keadaan stres akut, yaitu sebagai persediaan cadangan energi dan juga dianggap dapat mengkompensasi kehilangan volume dengan membantu pergerakan cairan ke kompartemen intravaskular melalui peningkatan tekanan osmotik. ${ }^{3,7-9}$ Namun, studi Leuven pada tahun 2001 oleh van den Berghe dkk. ${ }^{10}$ menyatakan bahwa dengan menjaga kadar glukosa darah dalam batas normal dapat meningkatkan kesintasan dan menurunkan morbiditas pada populasi sakit kritis. Setelah itu banyak penelitian yang dilakukan untuk mempelajari kondisi hiperglikemia pada pasien kritis, terutama pada populasi pasien dewasa. Berbagai penelitian tersebut juga melaporkan adanya hubungan antara hiperglikemia dengan mortalitas dan morbiditas pada pasien sakit kritis, serta manfaat dan perbandingan terapi insulin konvensional dan intensif dalam mempertahankan kondisi normoglikemia, serta pengaruhnya pada morbiditas serta mortalitas. Hasil yang didapatkan masih kontroversial.

Penelitian mengenai hiperglikemia pada pasien sakit kritis lebih banyak ditemukan pada populasi orang dewasa daripada anak. Insiden hiperglikemia pada anak sakit kritis dilaporkan berkisar antara 4\%-98\% tergantung dari batas nilai glukosa darah, frekuensi pemeriksaan, waktu pemeriksaan darah, dan populasi studi. Beberapa studi yang dilakukan pada populasi anak menunjukkan hiperglikemia pada sakit kritis berhubungan dengan peningkatan angka mortalitas dan morbiditas yang lebih buruk, seperti lama perawatan, penggunaan ventilasi mekanik, pemakaian obat vasoaktif, serta derajat disfungsi organ. Kelompok pasien yang mengalami hiperglikemia stres memiliki lama pemakaian ventilasi mekanik dan penggunaan inotropik yang lebih panjang, ${ }^{11-13}$ serta derajat disfungsi organ yang lebih berat. ${ }^{12,14,15}$

Dari pengamatan sering ditemukan keadaan hiperglikemia pada anak yang sakit berat. Di Indonesia, baru satu penelitian kecil dengan 15 subjek oleh Nurnaningsih $\mathrm{dkk}^{2}$ yang meneliti kondisi hiperglikemia pada anak dengan perawatan intensif di PICU, dan mencari korelasi hiperglikemia dengan derajat disfungsi organ. Penelitian mengenai hiperglikemia pada pasien anak yang sakit kritis dan menghubungkannya dengan sistem skoring masih sedikit sehingga penelitian dalam bidang ini masih diperlukan untuk mengetahui prevalens, karakteristik subjek yang menderita hiperglikemia, serta hubungannya dengan luaran dan derajat disfungsi organ.

\section{Metode}

Penelitian analitik potong lintang yang dilakukan di PICU RSCM Jakarta pada semua anak sakit kritis pada Maret- Juni 2011. Populasi target adalah semua anak sakit kritis di Indonesia dengan populasi terjangkau adalah semua anak dengan sakit kritis di PICU RSCM. Kriteria inklusi penelitian adalah anak usia 1 bulan-18 tahun yang baru dirawat di PICU RSCM selama periode penelitian dan mendapat nutrisi parenteral dengan glucose infusion rate (GIR) $4-6 \mathrm{mg} / \mathrm{kg} / \mathrm{menit}$ untuk anak dengan $\mathrm{BB} \leq 30 \mathrm{~kg}$ dan GIR $2-4 \mathrm{mg} / \mathrm{kg} / \mathrm{menit}$ untuk anak dengan $\mathrm{BB}>30 \mathrm{~kg}$. Kriteria eksklusi adalah subjek dengan diagnosis diabetes melitus, mendapat terapi steroid atau insulin, dan mendapat nutrisi oral atau enteral. Berdasarkan estimasi besar sampel dibutuhkan 85 subjek, yang diambil secara konsekutif.

Semua pasien yang memenuhi kriteria inklusi dilakukan pencatatan data dasar, meliputi umur, jenis kelamin, status gizi, serta data pemeriksaan fisis, Pasien tersebut kemudian dilakukan pemeriksaan darah untuk menghitung skor PELOD dan glukosa darah saat masuk PICU IKA RSCM (dalam waktu <24 jam). Data diolah menggunakan program SPSS 15.0 dan disajikan dalam bentuk tekstular dan tabular. 


\section{Definisi operasional}

Kriteria anak sakit kritis adalah semua anak yang dirawat di PICU IKA-RSCM. Hiperglikemia didefinisikan sebagai kadar glukosa darah sewaktu $>140 \mathrm{mg} / \mathrm{dL}$ pada saat masuk PICU IKA RSCM (dalam waktu $<24$ jam). Luaran dinilai dari pemakaian ventilasi mekanik, obat vasoaktif, dan disfungsi organ. Pemakaian ventilasi mekanik didefinisikan sebagai pasien yang mendapatkan bantuan pernapasan dengan ventilator mode continous positive airway pressure (CPAP), synchronized intermittent mandatory ventilation (SIMV), assist control (AC). Penggunan obat vasoaktif didefinisikan sebagai pasien yang mendapat salah satu atau lebih obat-obatan berikut, yaitu dopamin, dobutamin, epinefrin, atau norepinefrin. Disfungsi organ berat didefinisikan dengan skor PELOD $\geq 20$.

\section{Hasil}

Delapanpuluh tujuh subjek, sebagian besar berjenis kelamin laki-laki $(69,0 \%)$, dengan rasio lakilaki:perempuan 2,2:1. Distribusi usia subjek tidak normal dengan median usia 22 bulan (rentang 1 bulan-15 tahun). Sebaran tertinggi ditemukan pada kelompok usia 1-12 bulan (42,5\%). Sebagian besar subjek memiliki status gizi kurang $(50,6 \%)$. Jumlah pasien dengan diagnosis medis dan pascabedah memiliki perbandingan yang hampir sama. Karakteristik subjek penelitian tertera pada Tabel 1 .

Tabel 1. Karakteristik subjek penelitian $(n=87)$

\begin{tabular}{lcc}
\hline Karakteristik & Jumlah & $\%$ \\
\hline Jenis kelamin & & \\
$\quad$ Laki-laki & 60 & 69,0 \\
$\quad$ Perempuan & 27 & 31,0 \\
Usia & & \\
$\quad 1-12$ bulan & 37 & 42,5 \\
$\quad>1-5$ tahun & 25 & 28,7 \\
$\quad>5-18$ tahun & 25 & 28,7 \\
Status gizi & & \\
$\quad$ Kurang & 44 & 50,6 \\
$\quad$ Baik & 33 & 37,9 \\
$\quad$ Lebih & 10 & 11,5 \\
Diagnosis & & \\
$\quad$ Medis & 42 & 48,3 \\
Pasca-bedah & 45 & 51,7 \\
\hline
\end{tabular}

Tabel 2. Luaran penelitian

\begin{tabular}{lcc}
\hline Luaran & Jumlah & $\%$ \\
\hline Menggunakan & & \\
$\quad$ Vasoaktif & 7 & 8,0 \\
$\quad$ Ventilasi mekanik & 13 & 14,9 \\
$\quad$ Vasoaktif dan ventilasi mekanik & 8 & 9,2 \\
$\quad$ Tidak menggunakan keduanya & 59 & 67,8 \\
Skor PELOD & & \\
$\quad$ Tinggi $(\geq 20)$ & 10 & 11,5 \\
$\quad$ Rendah $(<20)$ & 77 & 88,5 \\
\hline
\end{tabular}

Tabel 3. Hubungan hiperglikemia dan karakteristik subjek

\begin{tabular}{|c|c|c|c|}
\hline \multirow[b]{2}{*}{ Karakteristik } & \multicolumn{2}{|c|}{ Hiperglikemia } & \multirow[b]{2}{*}{$\mathrm{p}$} \\
\hline & $\begin{array}{c}\mathrm{Ya} \\
(\mathrm{n}=25)\end{array}$ & $\begin{array}{c}\text { Tidak } \\
(\mathrm{n}=62)\end{array}$ & \\
\hline \multicolumn{4}{|l|}{ Jenis kelamin } \\
\hline Laki-laki & 20 & 40 & $0,158^{*}$ \\
\hline Perempuan & 5 & 22 & \\
\hline \multicolumn{4}{|l|}{ Usia } \\
\hline 1-12 bulan & 7 & 30 & $0,355^{*}$ \\
\hline$>1-5$ tahun & 10 & 15 & \\
\hline$>5-18$ tahun & 8 & 17 & \\
\hline \multicolumn{4}{|l|}{ Status gizi } \\
\hline Kurang & 13 & 31 & $0.181^{*}$ \\
\hline Baik & 11 & 22 & \\
\hline Lebih & 1 & 9 & \\
\hline \multicolumn{4}{|l|}{ Diagnosis } \\
\hline Medis & 9 & 33 & $0,146^{*}$ \\
\hline Pasca-bedah & 16 & 29 & \\
\hline
\end{tabular}

*Uji Chi-square

Tujuh $(8,0 \%)$ subjek mendapat obat vasoaktif dan $13(14,9 \%)$ menggunakan ventilasi mekanik, sedangkan $8(9,2 \%)$ menggunakan keduanya. Hanya sebagian kecil subjek $(11,5 \%)$ memiliki skor PELOD tinggi $(\geq 20)$ (Tabel 2.).

Hiperglikemia ditemukan pada 25/87 (28,7\%) subjek dengan distribusi kadar glukosa darah tidak normal. Median kadar glukosa darah untuk semua subjek $121 \mathrm{mg} / \mathrm{dL}$ dengan rentang 37 sampai 443 $\mathrm{mg} / \mathrm{dL}$. Hiperglikemia ditemukan lebih banyak pada subjek laki-laki, usia $>1-5$ tahun, gizi kurang, tetapi tidak ditemukan hubungan yang bermakna (Tabel 3). Subjek dengan diagnosis pasca-bedah juga memiliki proporsi hiperglikemia yang lebih besar (16/45) daripada subjek dengan diagnosis medis (9/42), tetapi memiliki perbedaan tidak bermakna. 
Tabel 4. Hubungan antara hiperglikemia dan luaran

\begin{tabular}{lccc}
\hline & \multicolumn{2}{c}{ Hiperglikemia } & \multirow{2}{*}{ Nilai $\mathrm{p}$} \\
\cline { 2 - 3 } & $\begin{array}{c}\text { Ya } \\
(\mathrm{n}=25)\end{array}$ & $\begin{array}{c}\text { Tidak } \\
(\mathrm{n}=62)\end{array}$ & \\
\hline Ventilasi mekanik & 9 & & \\
$\quad$ Ya & 16 & 12 & \\
$\quad$ Tidak & & 50 & \\
Obat vasoaktif & 6 & & \\
$\quad$ Ya & 19 & 53 & \\
$\quad$ Tidak & & & \\
Skor PELOD & 6 & 4 & ${ }^{* *} 0,350,03$ \\
$\quad$ Tinggi $(\geq 20)$ & 19 & 58 & \\
$\quad$ Rendah $(<20)$ & & & \\
\hline
\end{tabular}

* Uji Chi-square

\section{Hubungan antara hiperglikemia dengan luaran}

Terdapat 9/21 subjek pengguna ventilasi mekanik mengalami hiperglikemia. Proporsi tersebut lebih besar daripada 16/66 subjek tidak menggunakan ventilasi mekanik, $\mathrm{p}=0,101$. Proporsi subjek pemakai obat vasoaktif yang mengalami hiperglikemia (6/15) juga lebih banyak daripada subjek yang tidak menggunakan vasoaktif. Sebanyak 6/10 (60,0\%) subjek yang memiliki skor PELOD tinggi mengalami hiperglikemia. Proporsi tersebut lebih besar dibandingkan subjek yang memiliki skor PELOD rendah 19/77 (24,7), $(\mathrm{p}=0,03)($ Tabel 4).

\section{Pembahasan}

Hiperglikemia pada anak sakit kritis disebabkan oleh beberapa mekanisme, antara lain peningkatan glukoneogenesis dan glikogenolisis yang diperantarai oleh hormon counter-regulatory, serta penurunan transporter glukosa dengan ambilan glukosa yang berkurang oleh jaringan perifer, seperti otot dan hati. ${ }^{16}$ Belum ada kriteria pasti untuk mendiagnosis hiperglikemia pada pasien non-diabetes mellitus. Preissig $\mathrm{dkk}^{17}$ melakukan survei di 30 PICU, ditunjukkan bahwa sebagian besar dokter anak (>50\%) menentukan nilai cut-off glukosa darah antara 140 sampai $160 \mathrm{mg} /$ dL. Nilai cut-off yang dipakai pada penelitian kami adalah $140 \mathrm{mg} / \mathrm{dL}$, yang juga dipakai oleh beberapa peneliti lain. ${ }^{18-20}$ Peneliti lain menggunakan nilai cut-off yang berbeda, antara lain $126 \mathrm{mg} / \mathrm{dL}, 150 \mathrm{mg} / \mathrm{dL}$, dan $200 \mathrm{mg} / \mathrm{dL} .{ }^{7,11,13,21,22}$
Prevalens subjek yang mengalami hiperglikemia (kadar glukosa $>140 \mathrm{mg} / \mathrm{dL}$ ) pada penelitian kami adalah $28,7 \%$. Temuan tersebut hampir sama dengan penelitian lain yang menggunakan nilai ambang batas sama, yaitu penelitian Allen dkk. ${ }^{19}$ dan Ulate dkk. ${ }^{20}$ yang masing-masing menemukan prevalens hiperglikemia $27,2 \%$ dan $27,7 \%$. Srinivasan $\mathrm{dkk}^{18}$ dan Preissig $\mathrm{dkk}^{28}$ juga menunjukkan prevalens hiperglikemia dengan batasan nilai ambang yang sama dan didapatkan hasil yang tidak jauh berbeda, yaitu $33,5 \%$ dan $20 \%$.

Masalah lain dalam menentukan prevalens hiperglikemia adalah waktu pemeriksaan kadar glukosa yang paling dapat memprediksi luaran. Untuk menentukan hiperglikemia berdasarkan pemeriksaan glukosa saat masuk PICU. Sebagian besar penelitian yang sudah pernah dilakukan pada anak dan dewasa memang menggunakan kadar glukosa saat masuk PICU. ${ }^{7,19}$ Namun, penelitian Krinsley $\mathrm{dkk}^{24}$ pada pasien ICU dewasa menunjukkan bahwa nilai rerata kadar glukosa darah dan kadar glukosa puncak lebih dapat memprediksi luaran daripada nilai glukosa saat masuk PICU. Faustino $\mathrm{dkk}^{7}$ mendapatkan prevalens hiperglikemia yang lebih tinggi apabila menggunakan kadar glukosa puncak daripada kadar glukosa saat masuk PICU, penunjukkan dengan menggunakan kadar glukosa saat masuk PICU dapat menyebabkan prevalens hiperglikemia yang lebih rendah.

\section{Hubungan antara hiperglikemia dengan karakteristik subjek}

Subjek laki-laki pada penelitian kami (20/25 subjek) ditemukan lebih banyak mengalami hiperglikemia 
dibandingkan dengan yang tidak (40/62 subjek), tetapi tidak ditemukan adanya perbedaan. Hasil penelitian kami serupa dengan Preissig dkk. ${ }^{25}$ yang juga tidak mendapatkan perbedaan. Alaei $\mathrm{dkk}^{26}$ juga menemukan bahwa subjek laki-laki memiliki angka kejadian hiperglikemia tersering daripada perempuan, dan perbedaan ini bermakna $(\mathrm{p}=0,038)$. Ketiga temuan di atas tidak sama dengan penelitian Branco $\mathrm{dkk}^{27}$ dengan subjek pasien sepsis, ditemukan bahwa subjek laki-laki lebih sedikit mengalami hiperglikemia (14/28 subjek) dibandingkan dengan yang tidak (24/29 subjek) $(\mathrm{p}=0,02)$. Tidak ditemukan alasan yang menjelaskan hubungan antara jenis kelamin dan hiperglikemia pada penelitian sebelumnya.

Pada penelitian kami, kelompok usia dan status gizi tersering mengalami hiperglikemia adalah usia $>1$ -5 tahun dan status gizi kurang, tetapi tidak terdapat hubungan yang bermakna terhadap hiperglikemia. Penelitian yang telah ada tidak melakukan pengelompokkan, melainkan membandingkan rerata usia subjek dan berat badan subjek yang mengalami hiperglikemi dan tidak hiperglikemia. Hasil penelitian kami senada dengan studi oleh Preissig dkk, ${ }^{25}$ Alaei dkk, ${ }^{26}$ dan Branco $\mathrm{dkk}^{27}$ yang menemukan tidak ada perbedaan rerata usia dan berat badan yang bermakna antara kelompok hiperglikemia dan tidak hiperglikemia.

Pada penelitian kami 9/42 subjek yang dirawat dengan diagnosis medisjdan 16/45 dengan diagnosis pasca-bedah mengalami hiperglikemia. Hasil tersebut berbeda dengan penelitian oleh Preissig $\mathrm{dkk}^{15}$ yang menemukan pasien dengan diagnosis medis lebih banyak mengalami hiperglikemia (63\%) dibandingkan pasien dengan diagnosis pasca-operasi (37\%). Namun, pada penelitian tersebut Preissig $\mathrm{dkk}^{15}$ menyatakan baik subjek dengan diagnosis medis maupun pasca-bedah rentan dan memiliki risiko yang sama untuk terjadinya hiperglikemia Tidak ada perbedaan kadar glukosa, kebutuhan insulin, atau lamanya hiperglikemia yang bermakna di antara kedua kelompok tersebut.

\section{Hubungan antara hiperglikemia dan luaran}

Kami menemukan proporsi subjek yang mengalami hiperglikemia lebih besar pada subjek yang menggunakan ventilasi mekanik dibandingkan subjek yang tidak, tetapi tidak berbeda secara statistik. Preissig $\mathrm{dkk}^{15}$ menemukan angka yang lebih besar, yaitu $60 \%$ pasien yang memerlukan ventilasi mekanik. Penelitian lainnya oleh Pressig $\mathrm{dkk}^{28}$ menunjukkan hasil yang tidak jauh berbeda yaitu hiperglikemia ditemukan pada $65,5 \%$ subjek yang menggunakan ventilasi mekanik. Penelitian Branco $\mathrm{dkk}^{11}$ dengan populasi penelitian pasien bronkiolitis dan semua subjeknya menggunakan ventilasi mekanik ditemukan proporsi hiperglikemia $72 \%$. Peningkatan glukosa memiliki efek langsung terhadap sitokin dan peningkatan produksi TNF alfa, IL-1, dan IL-6. Selain itu, hiperglikemia juga akan mengaktivasi jalur protein kinase $\mathrm{C}$, poliol, dan spesies oksigen reaktif yang menyebabkan disfungsi mitokondria dan kerusakan sel sehingga meningkatkan inflamasi dan memperpanjang lama pemakaian ventilasi mekanik.

Enam diantara 15 subjek pengguna vasoaktif mengalami hiperglikemia dengan perbedaan yang tidak bermakna dibandingkan 19/72 (26,4\%) subjek yang tidak menggunakan vasoaktif mengalami hiperglikemia. Proporsi tersebut tidak jauh berbeda dari penelitian Branco $\mathrm{dkk}^{11}$ yang meneliti anak dengan bronkiolitis pengguna ventilasi mekanik. Enam dari 11 subjek pengguna vasoaktif mengalami hiperglikemia. Penelitian Preissig $\mathrm{dkk}^{15}$ menunjukkan jumlah yang lebih tinggi, yaitu $90 \%$ pasien yang memerlukan vasoaktif terjadi hiperglikemia, sehingga disarankan dilakukan pemeriksaan glukosa darah rutin pada pasien yang memerlukan bantuan vasoaktif. Proporsi tersebut hampir sama dengan temuan Day $\mathrm{dkk}^{12}$ yang menemukan $93,1 \%$ subjek pengguna vasoaktif mengalami hiperglikemia. Skrining hiperglikemia dengan melakukan pemeriksaan glukosa darah lebih sering dapat meningkatkan kemampuan identifikasi subjek yang mengalami hiperglikemia. Preissig $\mathrm{dkk}^{28}$ menjelaskan bahwa banyak faktor pada sakit kritis yang dapat menyebabkan disfungsi sel beta, antara lain peningkatan sitokin proinflamasi, katekolamin endogen dan eksogen, serta glukokortikoid. Katekolamin berperan pada disfungsi sel beta dan resistensi insulin, tetapi katekolamin eksogen dapat lebih menyebabkan disfungsi sel beta pada anak.

Penggunaan skor PELOD pada penelitian kami karena luaran adalah disfungsi organ, berbeda dengan PRISM-III dan PIM yang menggunakan mortalitas sebagai luaran. ${ }^{29}$ Skor PELOD dapat dipakai sebagai ukuran luaran karena kegagalan dari tiap organ dapat dinilai dari waktu ke waktu. ${ }^{30}$ Skor PELOD hanya dilakukan satu kali yaitu saat masuk PICU. Leteurtre $\mathrm{dkk}^{30}$ membagi skor PELOD yang dilakukan pada hari pertama menjadi 3 kelompok, yaitu rendah (< $10)$, sedang (10-19), dan tinggi ( $\geq 20)$, dengan nilai 
cut-off 10 dan 20 berhubungan dengan peningkatan mortalitas. Kami juga menggunakan nilai cut-off skor PELOD 20 dan didapatkan 10 subjek yang memiliki nilai PELOD $\geq 20$.

Proporsi subjek yang mengalami hiperglikemia ditemukan lebih banyak pada subjek yang memiliki skor PELOD tinggi, yaitu 6/10 subjek, dibandingkan 19/77 pada subjek dengan skor PELOD rendah. Perbedaan tersebut bermakna secara statistik $(\mathrm{p}=0,03)$. Temuan kami serupa dengan penelitian Yung $\mathrm{dkk}^{14}$ yang menunjukkan adanya hubungan bermakna antara hiperglikemia awal dengan skor PELOD $\geq 10$ (RO 2,11; IK 95\% 1,22-3,66; $\mathrm{p}=$ 0,008 ), dan skor PELOD $\geq 12$ (RO 3,26; IK 95\% 2,08- 4,70; $<<0,001$ ), serta mortalitas (RO 2,86; $95 \%$ IK $1,18-6,92 ; \mathrm{p}=0,02)$.

\section{Kesimpulan}

Prevalens hiperglikemia pada anak sakit kritis adalah 28,7\%. Proporsi subjek yang mengalami hiperglikemia lebih besar pada anak sakit kritis dengan derajat disfungsi organ berat (skor PELOD tinggi) dibandingkan dengan disfungsi organ ringan (skor PELOD rendah). Karakteristik subjek (jenis kelamin, usia, status gizi, dan diagnosis saat masuk) tidak terbukti berhubungan dengan terjadinya hiperglikemia pada sakit kritis. Tidak terbukti adanya perbedaan proporsi subjek yang mengalami hiperglikemia pada anak sakit kritis yang menggunakan ventilasi mekanik dan mendapat obat vasoaktif. Penelitian dengan desain penelitian kohort prospektif disarankan untuk melihat hubungan sebab-akibat hiperglikemia dengan luaran yang lebih baik, seperti mortalitas, dan lama rawat.

\section{Daftar pustaka}

1. Derde S, Vanhorebeek I, Van den Berghe G. Insulin treatment in intensive care patients. Horm Res 2009;71:2-11.

2. Nurnaningsih, Pudjiadi AH. Evaluation of substrate metabolism in critically ill pediatric patients. Berkala Ilmu Kedokteran 2008;40:75-80.

3. Verbruggen SCAT, Joosten KFM, Castillo L, van Goudoever JB. Insulin therapy in the pediatric intensive care unit. Clin Nutr 2007;26:677-90.

4. Nasraway SA. Hyperglycemia during critical illness.
JPEN J Parenter Enteral Nutr 2006;30:254-8.

5. Mizock BA. Alterations in carbohydrate metabolism during stress: A review of the literature. Am J Med 1995;98:75-84.

6. Klein GW, Hojsak JM, Rapaport R. Hyperglycemia in the pediatric intensive care unit. Curr Opin Clin Nutr Metab Care 2007;10:187-92.

7. Faustino EV, Apkon M. Persistent hyperglycemia in critically ill children. J Pediatr 2005;146:30-4.

8. McCowen KC, Malhotra A, Bistrian BR. Stress-induced hyperglycemia. Crit Care Clin 2001;17:107-24.

9. Van den Berghe G. Insulin therapy for the critically ill patient. Clin Cornerstone 2003;5:56-63.

10. Van den Berghe G, Wouters P, Weekers F, Verwaest C, Bruyninckx F, Schetz M, dkk. Intensive insulin therapy in critically ill patients. N Engl J Med 2001;345:135967.

11. Branco RG, Tasker RC. Glycemic level in mechanically ventilated children with bronchiolitis. Pediatr Crit Care Med 2007;8:546-50.

12. Day KM, Haub N, Betts H, Inwald DP. Hyperglycemia is associated with morbidity in critically ill children with meningococcal sepsis. Pediatr Crit Care Med 2008;9:636-40.

13. Klein GW, Hojsak JM, Schmeidler J, Rapaport R. Hyperglycemia and outcome in the pediatric intensive care unit. J Pediatr 2008;153:379-84.

14. Yung M, Wilkins B, Norton L, Slater A. Glucose control, organ failure, and mortality in pediatric intensive care. Pediatr Crit Care Med 2008;9:147-52.

15. Preissig C, Rigby MR. Pediatric critical illness hyperglycemia: Risk factors associated with development and severity of hyperglycemia in critically ill children. J Pediatr 2009; 155:734-9.

16. Verhoeven JJ, Hokken-Koelega ACS, den Brinker M, Hop WJC, van Thiel RJ, Bogers AJJC. dkk. Disturbance of glucose homeostasis after pediatric cardiac surgery. Pediatr Cardiol 2011;32:131-8.

17. Preissig CM, Rigby MR. A disparity between physician attitudes and practice regarding hyperglycemia in pediatric intensive care units in the United States: a survey on actual practice habits. Crit care 2010;14:R11

18. Srinivasan V, Spinella PC, Drott HR, Roth CL, Helfaer MA, Nadkarni V. Association of timing, duration, and intensity of hyperglycemia with intensive care unit mortality in critically ill children. Pediatr Crit Care Med 2004;5:329-36.

19. Allen HF, Rake A, Roy M, Brenner D, McKiernan CA. Prospective detection of hyperglycemia in critically ill 
children using continous glucose monitoring. Pediatr Crit Care Med 2008;9:153-8.

20. Ulate KP, Falcao GCL, Bielefeld MR, Morales JM, Rotta AT. Strict glycemic targets need not be so strict: A more permissive glycemic range for critically ill children. Pediatrics 2008;122:e898-e904.

21. Wintergerst KA, Buckingham B, Gandrud L, Wong BJ, Kache S, Wilson DM. Association of hypoglycemia, hyperglycemia, and glucose variability with morbidity and death in the pediatric intensive care unit. Pediatrics 2006;118:173-9.

22. Hirshberg E, Larsen G, Van Duker H. Alterations in glucose homeostasis in the pediatric intensive care unit: Hyperglycemia and glucose variability are associated with increased mortality and morbidity. Pediatr Crit Care Med 2008;9:361-6.

23. Preissig CM, Hanser I, Roerig P, Rigby MR. A protocolized aproach to identify and manage hyperglycemia in a pediatric critical care unit. Pediatr Crit Care Med 2008;9:581-8.

24. Krinsley JS. Effect of an intensive glucose management protocol on the mortality of critically ill adult patients.
Mayo Clin Proc 2004;79:992-1000.

25. Preissig CM, Rigby MR, Maher KO. Glycemic control for postoperative pediatric cardiac patients. Pediatr Cardiol 2009;30:1098-104.

26. Alaei F, Davari PN, Alaei M, Azarfarin R, Soleymani E. Postoperative outcome for hyperglycemic pediatric cardiac surgery patients. Pediatr Cardiol. 2011 Aug 18. [Epub ahead of print]. DOI 10.1007/s00246-011-00603.

27. Branco RG, Garcia PCR, Piva JP, Casartelli CH, Seibel V, Tasker RC. Glucose level and risk of mortality in pediatric septic shock. Pediatr Crit Care Med 2005;6:470-2.

28. Preissig CM, Rigby MR. Hyperglycaemia results from beta-cell dysfunction in critically ill children with respiratory and cardiovascular failure: a prospective observational study. Crit care 2009;13:R27.

29. Kneyber MCJ. Prognostic scoring in critically ill children: what to predict? CMAJ 2010;182:1155-6.

30. Leteutre S, Duhamel A, Grandbastien B, Proulx F, Cotting J, Gottesman R, dkk. Daily estimation of the severity of multiple organ dysfunction syndrome in critically ill children. CMAJ 2010;182:1181-7. 